\title{
From active joining to child-led participation: A new approach to examine participation in teaching practice
}

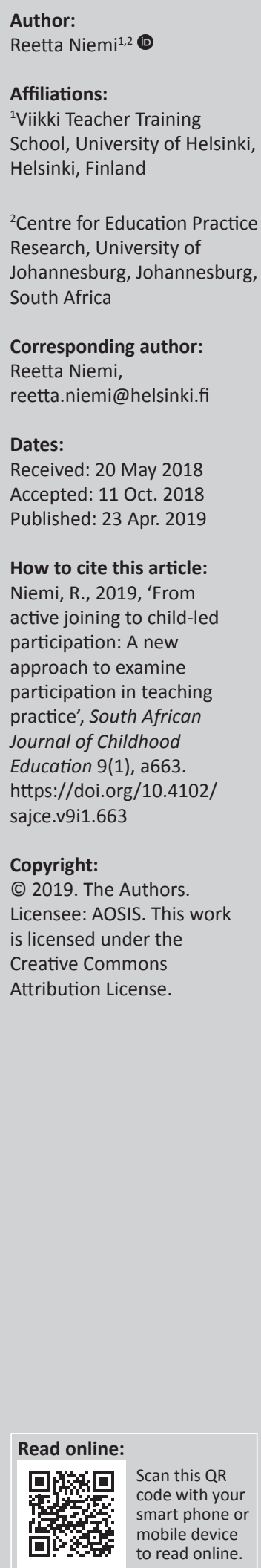

Background: The new core curriculum for basic education in Finland emphasises the interrelation between learners' participation and multidisciplinary learning. Each learner must be provided with an opportunity to join at least one multidisciplinary learning module each year. Hence, student teachers also implement a multidisciplinary learning module as part of their teaching practice at the University of Helsinki.

Aim: In this article, I describe how two multidisciplinary learning modules were implemented by four third-year student teachers in a teacher training school and how they were educated to analyse the different forms of participation in their teaching.

Setting: The research question of this article is as follows: How do different teaching practices used in multidisciplinary learning modules support learners' participation?

Methods: The data of this study consist of two documentation forms: two semi-structured group interviews and a field note diary.

Results: The results showed that most of the practices used in multidisciplinary learning modules supported an active joining form of participation and a collaborative form of participation. In the multidisciplinary learning modules, a child-oriented form of participation was supported through practices that related to creating artistic learning outcomes; however, no practices supported a child-led form of participation.

Conclusion: In this study, the student teachers learned to analyse the different forms of participation in their teaching. Nevertheless, more data about the workability of the mentoring method in other contexts are needed.

Keywords: learners' participation; multidisciplinary learning modules; teaching practice; teacher training; practitioner research; teacher professional development.

\section{Introduction}

In the 21st century, Finland has become famous for its educational system. Because of its reputation, there has been considerable international interest in Finland's implementation of the new national curriculum that took place in 2016. Some of the main changes in the Finnish national core curriculum for basic education (Finnish National Board of Education [FNBE] 2014) are connected to two interrelated elements: pupils' participation and multidisciplinary learning modules.

Firstly, pupils' participation is one mission in basic education in Finland. The Finnish national core curriculum states that basic education should reinforce the pupils' positive identities as human beings, learners and community members and promote participation, a sustainable way of living and growth into active citizens who use their democratic rights and freedoms responsibly. It also states that participating in civic activity is a basic precondition for an effective democracy. Skills in participation and involvement as well as a responsible attitude towards the future may only be learned by practising (FNBE 2014:19-25). In Finland, schoolwork should be based on learners' participation by ensuring that they are heard. The learners' involvement in planning their own schoolwork and group activities is also seen as a natural way of reinforcing participation (FNBE 2014:37).

All of these aspects of participation given in the core curriculum apply to the political and social dimensions of participation defined in educational literature. Political participation means making an impact, influencing the community, taking part in decision-making and taking responsibility. In schools, the political dimension usually means working with the school councils 
and mimicking the political structures of adult society. Social participation is concerned with the sense of community, belonging, membership and positive social interdependence. A learner has to be a member of the group or the community; one has to be able to act in a group and feel accepted as part of the group (Kiilakoski, Gretschel \& Nivala 2012; Niia et al. 2015; Thomas 2007). I agree with Bae (2009), who points out that the phenomenon of learners' participation is too often reduced to mean learners' role in decision-making and that the social dimension of participation receives less emphasis.

In order to support pupils' participation, the current national curriculum emphasises the role of multidisciplinary learning modules. It states that to safeguard learners' opportunities to examine wholes and engage in exploratory work that is of interest to learners, they must be provided with opportunities to join a multidisciplinary learning module at least once during a school year. The curriculum also clarifies that the duration of the learning modules must be long enough to give pupils time to focus on the contents of the module and work in a goal-oriented and versatile manner over the long term. It also states the importance of strengthening the learners' participation through learning modules by offering learners opportunities for involvement in the planning of the objectives, contents and methods of the studies and ways to raise issues that they find meaningful (FNBE 2014:23-33). Despite being from the compulsory role of multidisciplinary learning modules, the national core curriculum has always supported and still supports subjectbased teaching through subject-based goals. That has confused many teachers as they wonder how to come up with a holistic multidisciplinary module while at the same time ensuring that the requirements of the subject-based curriculum are met.

In this article, I focus on two problems. I describe how two multidisciplinary learning modules were implemented by four student teachers in the Viikki Teacher Training School from September to December 2017 by connecting subjectbased goals and pupils' participatory role in planning, implementing and evaluating the module. I also describe how the model of the four forms of participation was used in teaching practice in promoting student teachers' skills to reflect different forms and dimensions of participation. My research question is: How do different teaching practices used in multidisciplinary learning modules support learners' participation?

In the next section, I draw a picture from previous models of participation and present a new approach to analysing participation in teaching. After that, I describe my method, data collection, analysis and results. I also discuss some ethical problems related to this study. In the conclusion, I look ahead and suggest how the results of this study could be applied in teacher education.

\section{Models of participation}

As participation practice has grown, so has the number of guides and models to support the practice (e.g. Hart 1992;
Landsdown 2001, 2010; Lundy 2007; Reddy \& Ratna 2002; Shier 2001; Treseder 1997). One of the most influential models has been Hart's (1992) ladder of participation, in which he presents an eight-step model that begins with non-participation: (1) manipulation, (2) decoration and (3) tokenism. The model ends with degrees of participation: (4) assigned but informed; (5) consulted and informed; (6) adult-initiated, shared decisions with children; (7) childinitiated and directed and (8) child-initiated, shared decisions with adults.

Hart's model has also been substantially critiqued. It has been said that it implies a necessary sequence to children's developing competence in participation (Kirby \& Woodhead 2003:243; Reddy \& Ratna 2002:28). It has also been questioned whether one should even mention different levels of participation. Jensen (2000) has suggested that the rungs of the ladder can be described as different forms rather than different levels of participation.

In his later work, Hart (2008) pointed out that the ladder of participation addresses only a rather narrow range of ways in which most children in the world participate in their communities. It focuses on programmes or projects rather than on children's everyday informal participation in their communities. The ladders focus instead on describing the varying roles adults play in relation to children's participation. In fact, the ladder is primarily about the degree to which adults and institutions afford or enable children's participation.

Landsdown (2010) suggested that the importance of finding key indicators to evaluate evidence of cultural climate in which the right of children to be heard and taken seriously is established. She also emphasised that it is necessary to be able to measure the extent, quality and impact of actual participation in which children are engaged. From her point of view, children should even be able to participate in evaluating what participation is taking place.

Landsdown (2010) classified children's participation on three levels: consultative, collaborative and child-led. Firstly, consultative participation is a level on which adults seek children's views to build knowledge together. The actions are adult-led and managed and children do not join the decision-making. Secondly, collaborative participation provides a greater degree of partnership between adults and children. On this level, children can be involved in designing and undertaking research, showing representations on boards and committees. Collaborative participation provides an opportunity for shared decision-making with adults. Thirdly, child-led participation occurs when children are afforded the space and opportunity to identify issues of concern, initiate activities and advocate for themselves. The role of adults is to act as facilitators to enable children to pursue their own objectives through provision of information, advice and support. 
According to Sinclair (2004), children's participation in decision-making is complex: it is undertaken for different purposes and is reflected in different levels of involvement, contexts and activities. Different contexts constitute a different form of participation. Participation as a group phenomenon is different from personally experienced participation. What is crucial is that those involved understand these complexities so that they can match appropriately the nature of their activity to its purpose and to the decision-making context and the appropriate level of power-sharing. Sinclair (2004) points out that only when the adults have thought this through will they be able to engage effectively with children.

Similarly, in schools one can find different contexts in which participation has different purposes. Learners' participation in breaks, lessons, school councils and special school events can look different. In the literature, it is common that examples related to learners' participation in schools are organised around specific projects, which often are activities that are 'added on' to normal classroom practices (Malone \& Hartung 2010:32), instead of a focus on lessons and teaching practices. In this study, my concern relates to learners' participation in actual lessons in different school practices.

My ideas of participation follow the four aspects defined by Kiilakoski et al. (2012). Firstly, participation is a relational phenomenon that, secondly, involves a formal and informal recognised position as an agent. Thirdly, participation should manifest in physical, oral and verbal events and actions and, fourthly, it should produce a feeling of participation. In the next section, I draw a four-form approach to be used as a tool to see how teachers as representatives of a school institution can support different forms of participation through their teaching practices.

\section{Four forms of participation in classroom practices}

After the new core curriculum (FNBE 2014) was launched in Finland, the concept of participation has spread everywhere, but it has also caused problems. The concept has been repeated as a canonical script without being analysed and explained. It has also been considered as a phenomenon that either exists or does not (Tammi \& Hohti 2017). Because previous models of participation relate rather to contexts in which learners work with adults in programmes and committees than on lessons, my colleagues and I developed the model of the four forms of participation suitable for use in classroom practice (Niemi, Kumpulainen \& Lipponen 2018). We use the concept of form instead of level, because we think that each form is important and we do not want to promote one form as better than another. In the original model, we focused on learners' role in decision-making on lessons. In this article, I continue to develop these forms by placing a stronger emphasis on the social dimension of participation.

The first form of participation is called active joining. This form relates to Hart's Levels 3-4 and to Landsdown's ideas of consultative participation but it also relates to the social dimension of participation. In this form, a teacher creates learning activities in which a learner can work actively, bring out knowledge and thoughts from the content and work as a teacher's assistant. However, all activities are led by a teacher and learners do not share power, but these activities often support learners' everyday communication and relatedness to others.

The second form of participation is called collaborative participation. This form has adopted features from Hart's Levels 5-6 and from Landsdown's ideas of collaborative participation. In this form, a teacher is the one who makes the first input by choosing topics for the lessons defined in the curriculum. After that, in a shared discussion between learners and teacher, the lesson finds its format. Learners' previous knowledge, thoughts and ideas together form the direction of the lesson in collaboration with a teacher. In this form, learners have an impact on decision-making, but this form strongly emphasises the social dimension of participation.

Child-oriented participation is connected to Hart's Levels 7-8 and to Landsdown's level of child-led participation. In this form, learning situations are based on learners' own ideas and wishes and a teacher's role is to work as assistant and facilitator, who helps learners to accomplish their ideas. In this form, a teacher's role is continually present by setting timetables, helping group work and giving suggestions to improve learning outcomes. In this form, learners have a recognised role as agents who are able to influence decisionmaking in terms of their own learning and take responsibility for their own learning.

In both Hart's (1992) and Landsdown's (2010) models all the levels are connected to adults' existence and adults' role in children's actions. That aspect has been critiqued by asking whether it is possible that children can act without adults (Kirby \& Woodhead 2003). In our approach, the form of childled participation refer to those situations that happen without adult interference. Those situations may occur in play that begins, continues and ends according to children's own will. By child-led participation we also mean situations in which a learner takes a lead from a classroom activity and shares his or her expertise on behalf of the classroom community. This form of participation highlights learners' independent role in decision-making.

\section{Methodology of the study and data collection}

This study is practitioner research that has elements from action research and design-based research. Practitioner research can be seen as an umbrella of different approaches that focus on an intentional and systematic study of one's own practice (Dinkelman 2003:8; see also Heikkinen, De Jong \& Vanderlinde 2016). In education, practitioner research can be seen as any research carried out by teachers and 
other education professionals into aspects of their work (McLaughlin 2011).

In this study, I conducted a small-scale intervention in the functioning of the school setting and examined the effects of this intervention. There are features that are context-specific, participatory and collaborative. These elements are characteristic of action research (Carr \& Kemmis 1986; Cohen \& Manion 1994:186). However, I have also attempted to create a model for teacher education to educate student teachers to understand the different forms of participation. My attempt to design a method to mentor student teachers that is not dependent on context gives this study features from design-based research (Cohen \& Manion 1994:186; Van den Akker et al. 2006).

The study took place in a teacher training school in the city of Helsinki, Finland. The participants in the study were third-year student teachers (three women and one man) who conducted their second teaching practice during the study. By the time of the research, the pupils (13 girls and 12 boys) of the classroom were in the third grade (approximately 9 years old). The classroom had several multicultural pupils, five of whom did not speak Finnish as a first language. In this study, I have a triple role: I am a teacher to the learners, a mentor to the student teachers and a researcher.

Data collection took place from September to December 2017. All data were collected during a 50-lesson teaching practice. Each teaching practice took 1 week for planning and 5 weeks for teaching. During the teaching practice, student teachers taught five different subjects and conducted a multidisciplinary learning module from the contents. Table 1 describes the multidisciplinary learning modules that were produced in teaching practices. The data consisted of two forms that document the student teachers' reflections from teaching methods, two group interviews and my field note diary. Student teachers' plans for multidisciplinary module sessions $(n=20)$ have also been included in the writing process to verify the order of sequence during multidisciplinary learning modules.

The student teachers completed a documentation form after each week, after approximately 10-12 lessons. The documenting began with reflecting on all the different teaching practices the student teachers had used and then they filled out the form in (Figure 1) according to their experiences. After the teaching practice, I interviewed the student teachers.

\section{Ethical considerations}

In practitioner research, a researcher always has an impact on the results (Heikkinen et al. 2016). In this study, I am one of the authors behind the four forms of participation (Niemi, Kumpulainen \& Lipponen 2018) that were used as a theoretical starting point. Because I am the one who taught
TABLE 1: The multidisciplinary learning modules of the study.

\begin{tabular}{|c|c|c|c|}
\hline Time of MLM & Title of MLM & Goals & Learning outcome of MLM \\
\hline Sep-Oct & $\begin{array}{l}\text { Heat - weather } \\
\text { and its impact } \\
\text { on children's } \\
\text { lives }\end{array}$ & $\begin{array}{l}\text { To understand how } \\
\text { the position of } \\
\text { Finland and South } \\
\text { Africa on the earth } \\
\text { has an impact on } \\
\text { weather. } \\
\text { To understand heat } \\
\text { as a physical } \\
\text { phenomenon. }\end{array}$ & $\begin{array}{l}\text { A teaching video made by } \\
\text { all learners together for } \\
\text { Soweto Ujabue School on } \\
\text { how weather in Finland is } \\
\text { different from that in } \\
\text { South Africa and how that } \\
\text { has an impact on Finnish } \\
\text { children's lives. }\end{array}$ \\
\hline Nov-Dec & $\begin{array}{l}\text { Environment } \\
\text { and active } \\
\text { citizenship }\end{array}$ & $\begin{array}{l}\text { To learn to do } \\
\text { science-based } \\
\text { research from soil, } \\
\text { water and air. } \\
\text { To understand how to } \\
\text { save soil, water and } \\
\text { the environment. } \\
\text { To learn skills to } \\
\text { engage in active } \\
\text { citizenship. }\end{array}$ & $\begin{array}{l}\text { Each learner wrote a letter } \\
\text { to a representative of the } \\
\text { city council on one of the } \\
\text { topics she or he had } \\
\text { studied and learned about } \\
\text { and suggested issues the } \\
\text { representative should } \\
\text { improve in city council. }\end{array}$ \\
\hline
\end{tabular}

MLM, multidisciplinary learning modules.

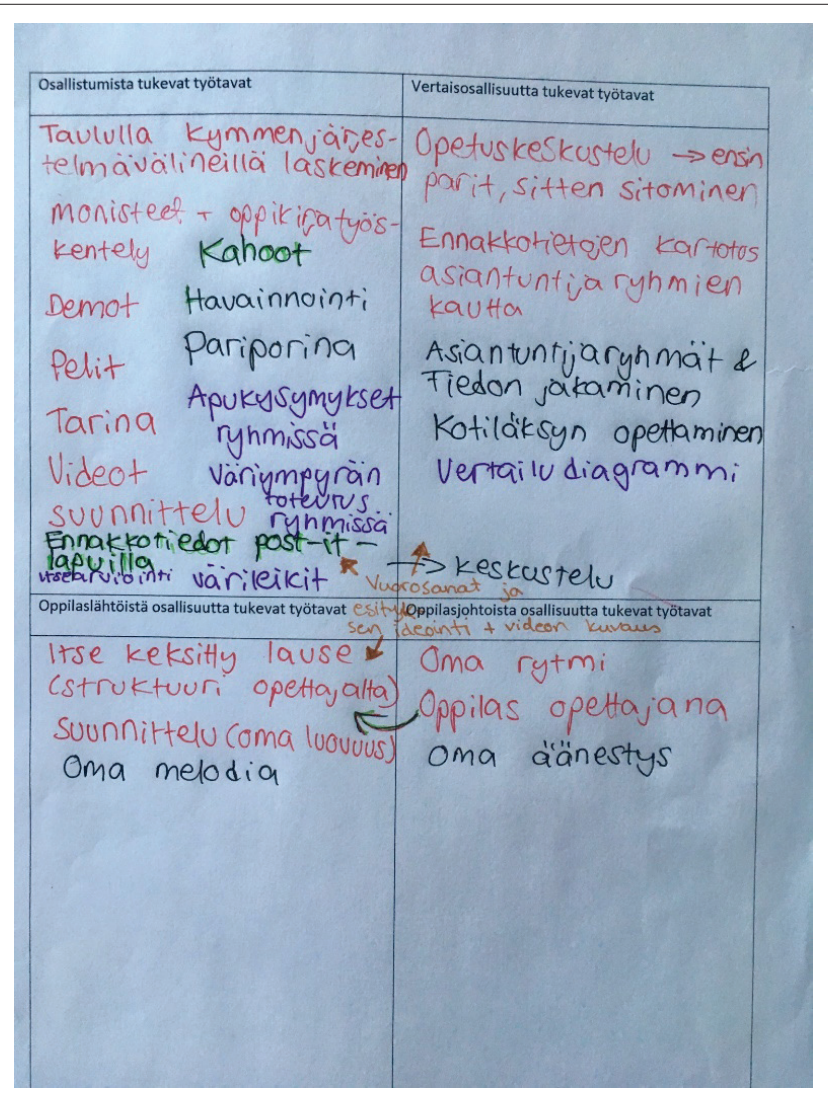

FIGURE 1: A documentation form that was used as a mentoring tool (Author's own work).

the meaning of each form to student teachers, my interpretations have had an impact on student teachers' thinking, which should be considered when interpreting the results of this study. In practitioner research, ethical issues are always to be considered carefully. Ethically it was important that I did not have an official power relationship to the student teachers through grading (in Finland there is no grading in teaching practice), but they were free to express their opinions without fearing an effect on their studies; however, my role as their mentor may still have had an impact on the results. There is always a possibility that they may have had some criticism that they did not want to share because they knew me. That is something to admit, not 
deny (see also Heikkinen et al. 2016). To increase the validity of this article, the student teachers were invited to read this article and correct my interpretations before sending the article to a journal for publication. I have also obtained permission to do this study from the leading principle of the school.

\section{Results}

\section{How do different teaching practices used in multidisciplinary learning modules support learners' participation?}

In the interviews, the student teachers viewed highly structured practices like answering teachers' questions, doing study book tasks, filling in forms and notebook work as practices that require pupils' active joining but do not give learners any opportunities to join power-sharing or support communication. In these multidisciplinary learning modules, there were not many of these practices and their purpose was to strengthen pupils' skills through repetition. The student teachers also noticed that these practices were easy to spot on this form, because there was no variation between learners' actions in these practices.

In those two multidisciplinary learning modules, the learners were able to join many kinds of learning games and play. They were also shown different videos during the modules. The student teachers also classified these practices to the form of active joining. In the learning modules, there were also many practices in which the learners completed scientific-based research and made observations from tests created by the student teachers. In those practices, pupils worked actively and communicated with their peers but they did not join in the decision-making. In the literature, there are many studies that have shown how much learners appreciate doing scientific research and joining games or play (e.g. Hopkins 2008; Niemi, Kumpulainen \& Lipponen 2015a, 2015b; Niemi et al. 2015). Even though these activities do not give learners a chance to join power-sharing, they still give learners a chance to experience a social dimension of participation through everyday communication (see also, Bae 2009). When solving problems and playing games, learners can be heard and communicate freely with classmates and feel a sense of relatedness to others.

The student teachers viewed investigative learning practices as a collaborative form of participation. In these two learning modules pupils developed their own research questions from a topic set in the curriculum. In these investigative practices, the learners also worked in expert groups and were coteachers to each other. The practices, which student teachers considered as a collaborative form of participation, related to activities in which they built knowledge together in dialogic form. For example, doing a Venn diagram together with learners and building up lessons according to learners' preknowledge were considered as practices in which learners were involved in designing and undertaking different kind of actions together with teachers (see also Landsdown 2010).
In the second learning module, pupils also conducted a selfevaluation of their own work. The learners joined an assessment discussion with student teachers according to their self-evaluations. The student teachers saw this practice as a collaborative form of participation, because input was provided by the student teachers but the learners had a significant role in setting goals for themselves for future projects. Even the student teachers had input into these practices; the learners had a recognised and active role in each practice. They were not only teacher's assistants (see Landsdown 2010) but they also had a role as active members of the classroom community who had an impact on the lesson's direction.

In the interviews, the student teachers mentioned that at the beginning of the multidisciplinary learning module, when they built conceptual knowledge and reached the subject-based goals set in the curriculum, the practices often supported an active joining form of participation or collaborative form of participation. After the teachers created the conceptual ground for the learners, the learners had a chance to plan how to express their learning and they were able to implement their learning in various ways, often artistically.

In these two multidisciplinary learning modules, the practices that supported a child-oriented form of participation related to processes of creating learning outcomes; writing a video script; filming a video; writing a letter to a representative of a city council; creating a scene of a play and composing a song. In these practices, learners were able to make decisions and the teacher's role was only to help learners if they were confronted with problems. These practices also forced learners to take responsibility for their own learning.

However, the student teachers pointed out that in this part of the learning module there were also learners who did not reach a child-oriented form of participation and who needed continual structure to guide their work. This result is similar to that of previous research; the form of participation is in relation to learners' capacities to participate (Hart 1992; Landsdown 2010; Sinclair 2004). In interviews the student teachers also revealed that in many cases it was easy to place a certain practice in a certain box on a documentation form. However, there were practices that began with one form and during the lesson evolved into another form of participation. Furthermore, learners' different capacities to join practices sometimes made it impossible to place a certain practice into a certain box. This critique clearly reveals the difficult aspects of participation. Researchers and teachers can try to understand different forms of participation but it is challenging to capture the phenomenon as whole. As Sinclair (2004) has said, participation as a group phenomenon is different from personally experienced participation. I still claim that if teachers understand these complexities, they can also appropriately match different practices to its purpose and to the decision-making context and the appropriate level of power-sharing (see also Sinclair 2004). 
TABLE 2: Results presented in the model of documentation form.

\begin{tabular}{ll}
\hline Participation & Description \\
\hline Active joining & - Answering teachers' questions \\
& - Doing study book tasks \\
& - Lempleting forms and notebook work \\
& - Scientific-based research
\end{tabular}

In this study, there was no single practice that was considered to support a child-led form of participation. However, when learners worked in groups, there were single moments that could be seen as a child-led form of participation. For example, in one group learners decided themselves to solve a problem through voting. The voting was implemented without the interference of the student teachers. Similarly, Hart (2008) has reported that children can reach the child-led form of participation only in play. In an interview, the student teachers mentioned that in this classroom there was one practice that supported a child-led form of participation; the learners can use one break per day for practising their own plays. On Fridays there is a lesson in which the learners present these performances. The programme of the lesson is made by learners and the lesson is guided by them. This lesson was not part of student teachers' multidisciplinary learning module, but because it was a major part of the class culture, it was revealed in the interviews. Table 2 presents the previous results by using the model of documentation form used in this study.

\section{Conclusion}

In Finland, achieving learners' participation is one mission of basic education. To promote learners' participation, each learner must be provided with an opportunity to join at least one multidisciplinary learning module per year. This practice has also caused questions: What do we mean by 'participation in learning'? How is it possible to create holistic multidisciplinary modules while at the same time ensuring that the requirements of the subject-based curriculum are met? Because of the compulsory nature of multidisciplinary learning modules, student teachers must also implement a multidisciplinary learning module as part of their teaching practice.

In this article, I have described the model of four forms of participation. In the study, I used that model as a tool in mentoring the student teachers to analyse their own work and to understand how different teaching practices promoted different forms of participation. At the beginning of each multidisciplinary learning module, when the conceptual base of the topic was built and when the work was based on reaching subject-based goals set in the curriculum, the practices mainly promoted an active joining form of participation and collaborative form of participation. When the multidisciplinary learning module went further and when the learners began to plan and implement their learning outcomes, the practices used supported a child-oriented form of participation. In the multidisciplinary learning modules, there were not any practices that supported a child-led form of participation. In this study, the student teachers also revealed the difficult essence of participation. We can try to understand different forms of participation, but it is challenging to capture the phenomenon, because participation as a group phenomenon is different from personally experienced participation (see also Sinclair 2004). It is crucial that the teachers involved understand these complexities so that they can match appropriately different practices to its purpose and to the decision-making context and the appropriate level of power-sharing (see also Sinclair 2004).

In this study, the student teachers experienced the model used in mentoring as beneficial in terms of their professional development. It also worked well in connecting the theory of participation to practice. When I look at the method through the lense of design-based research (e.g. Cohen \& Manion 1994:186; Van den Akker et al. 2006), I think that this method can be transferred to other contexts. It did not require any financial resources and all events occurred during an ordinary school day as part of everyday mentoring. I also think that in teacher education this method could be used in connecting other theories besides participation to practice. Even though the results were promising, this research has to be considered a minor-scale study. There is a need to do more research about the workability of this method in other contexts. However, I hope that this minor research provides the educational community with some new aspects of learners' participation in learning and inspires other practitioner researchers to try this method.

As Landsdown (2010) put it, it is necessary to be able to measure the extent, quality and impact of actual participation in which children are engaged. In this study, I was able to capture student teachers' reflection of different forms of participation that were promoted by the teaching practices used. According to Landsdown (2010), learners should join in the process of evaluating the processes in which they have participated. In this research, the method used focused only on student teachers' reflection and it did not include learners' voices. I give that critique to my own work but I also see that as a future challenge and a goal on which to focus in future studies.

My results are contextual but the issue of promoting learners' participation is global. I claim that Finland's educational system (see, e.g., Lanas \& Kiilakoski 2013), where primary school is decentralised, no teacher evaluation exists and the national curriculum offers teachers substantial pedagogical freedom, gives teachers the possibility of supporting learners' participation. In Finland, teachers' autonomy and trust in teachers' strong model of professionalism allow teachers to choose teaching practices that are appropriate for the particular learners and determine creative ways to 
implement learning. I believe that by supporting the autonomy of teachers, teachers can enhance the autonomy of learners also in other educational contexts. I hope that my article also raises discussion on that important issue.

\section{Acknowledgements Competing interests}

The author declares that she has no financial or personal relationships that may have inappropriately influenced her in writing this article.

\section{References}

Bae, B., 2009, 'Children's right to participate - Challenges in everyday interactions', European Early Childhood Education Research Journal 17(3), 391-406. https://doi. org/10.1080/13502930903101594

Carr, W. \& Kemmis, S., 1986, Becoming critical: Education, knowledge and action research, Falmer, London.

Cohen, L. \& Manion, L., 1994, Research methods in education, 4th edn., Routledge, London.

Dinkelman, T., 2003, 'Self-study in teacher education: A means and tool for promoting reflective practice', Journal of Teacher Education 54(1), 6-18. https://doi. org/10.1177/0022487102238654

Finnish National Board of Education (FNBE), 2014, Perusopetuksen opetussuunnitelman perusteet 2014 [Basics of Basic Education Curriculum 2014], viewed 06 January 2018, from http://www.oph.fi/download/163777_perusopetuksen opetussuunnitelman_perusteet_2014.pdf

Hart, R., 1992, Children's participation, from tokenism to citizenship, UNICEF, Florence, viewed 25 August 2018, from http://www.unicef-irc.org/publications/pdf/ childrens_participation.pdf

Hart, R., 2008, 'Stepping back from "the ladder": Reflections on a model of participatory work with children', in A. Reid, B.B. Jensen, J. Nikel \& V. Simovska
(eds.), Participation and learning. Perspectives on education and the environment, (eds.), Participation and learning. Perspectives

Heikkinen, H.L.T., De Jong, F.P.C.M. \& Vanderlinde, R., 2016, 'What is (good) practitioner research?', Vocations and Learning 9, 1-19. https://doi.org/10.1007/ practitioner research?

Hopkins, E.A., 2008, 'Classroom conditions to secure enjoyment and achievement: The pupils' voice. Listening to the voice of Every child matters', Education 36(4), 393-401. https://doi.org/10.1080/03004270801969386

Jensen, B.B., 2000, 'Participation, commitment and knowledge as components of pupil's action competence', in B.B. Jensen, K. Schnack \& V. Simovska (eds.), Critica environmental and health education - Research issues and challenges, pp. 219-238, Danish University of Education, Copenhagen.

Kiilakoski, T., Gretschel, A. \& Nivala, E., 2012, 'Osallisuus, kansalaisuus ja hyvinvointi' [Participation, citizenship and well-being], in A. Gretschel \& T. Kiilakoski (eds.) Demokratiaoppitunti. Lasten ja nuorten kunta 2000-luvun alussa, pp. 11-19, Nuorisotutkimusverkosto/Nuorisotutkimusseuran julkaisuja 118, Helsinki.

Kirby, P. \& Woodhead, M., 2003, 'Children's participation in society', in H. Montgomery, R. Burr \& M. Woodhead (eds.), Changing childhoods. Local and global, pp. 233-272, Open University Press, Chichester, IL.
Lanas, M. \& Kiilakoski, T., 2013, 'Growing pains: Teacher becoming a transformative agent', Pedagogy, Culture and Society 21(3), 343-360. https://doi.org/10.1080/1 4681366.2012.759134

Landsdown, G., 2001, Promoting children's participation in democratic decisionmaking, UNICEF, Florence, viewed 04 January 2018, from https://www.unicef-irc. org/publications/pdf/insight6.pdf

Landsdown, G., 2010, 'The realisation of children's participation rights: Critical reflections', in B. Percey-Smith \& N. Thomas (eds.), A handbook of children and young people's participation. Perspectives from theory and practice, pp. 11-23, Routledge, Abingdon.

Lundy, L., 2007, "Voice" is not enough: Conceptualising Article 12 of the United Nations Convention on the Rights of the Child', British Educational Research Journal 33(6), 927-942. https://doi.org/10.1080/01411920701657033

Malone, K. \& Hartung, C., 2010, 'Challenges of participatory practices with children', in B. Percey-Smith \& N. Thomas (eds.), A handbook of children and young people's participation: Perspectives from theory and practice, pp. 24-38, Routledge, London.

McLaughlin, C., 2011, 'Creating a place for research in schools. Flowing with a tide or swimming upstream?', in I.M. Saleh \& M.S. Khine (eds.), Practitioner research in education. Theory and best practices, Peter Lang Berlin, viewed 02 January 2018, from ProQuest Ebook Central, https://ebookcentral-proquest-com.libproxy. helsinki.fi/lib/helsinki-ebooks/detail.action?doclD=1054425

Niia, A., Almqvist, L., Brunnberg, E. \& Granlund, M., 2015, 'Student participation and parental involvement in relation to academic achievement', Scandinavian Journa of Educational Research 59(3), 297-315. https://doi.org/10.1080/00313831.201 4.904421

Niemi, R., Kumpulainen, K. \& Lipponen, L., 2015a, 'Pupils as active participants: Diamond ranking as a tool to investigate pupils' experiences of classroom practices', European Educational Research Journal 14(2), 138-150. https://doi. org $/ 10.1177 / 1474904115571797$

Niemi, R., Kumpulainen, K. \& Lipponen, L., 2015b, 'Pupils' documentation enlightening teachers' practical theory and pedagogical actions', Educational Action Research 23(4), 599-614.

Niemi, R., Kumpulainen, K., Lipponen, L. \& Hilppö, J., 2015, 'Pupils' perspectives on the lived pedagogy of the classroom', Education 3-13 43(6), 681-697.

Niemi, R., Kumpulainen, K. \& Lipponen, L., 2018, 'Osallistumista vai osallistamista? Osallisuuden tarkastelua monialaisen oppimiskokonaisuuden toteuttamisessa', Nuorisotutkimus 36(1), 22-35.

Reddy, N. \& Ratna, K., 2002, A journey in children's participation, The Concerned for Working Children, Vimanapura, viewed 06 January 2018, from https:// resourcecentre.savethechildren.net/sites/default/files/documents/2625.pdf

Shier, H., 2001, 'Pathways to participation: Openings, opportunities and obligations. A new model for enhancing children's participation in decision-making, in line with Article 12.1 of the United Nations Convention of the Right of the Child', Children and Society 15, 107-117. https://doi.org/10.1002/chi.617

Sinclair, R., 2004, 'Participation in practice: Making it meaningful, effective and sustainable', Children and Society 18, 106-118. https://doi.org/10.1002/chi.817

Tammi, T. \& Hohti, R., 2017, 'Lasten osallistuminen ja posthumanistinen ontologia: Urittuvaa ja emergenttiä kartoittamassa', Kasvatus \& Aika 11(1), 69-83.

Thomas, N., 2007, 'Towards a theory of children's participation', International Journa of Children's Rights 15, 199-218. https://doi.org/10.1163/092755607X206489

Treseder, P., 1997, Empowering children and young people: Training manual, Save the Children and Children's Rights Office, London.

Van den Akker, J., Gravemeijer, K., McKenney, S. \& Nieveen, N., 2006, Educational design research, Routledge, Abingdon. 